\title{
The Effect of Motivation Discipline Work, and Compensation to Employee's Performance at PT XYZ
}

\author{
Mohamad Hamdhani. MS ${ }^{1}$, Ahmad Badawi Saluy ${ }^{2}$ \\ \{m_hamdhani@yahoo.com¹, ahmad.badawi@mercubuana.ac.id ${ }^{2}$ \} \\ Universitas Mercu Buana, Jakarta, Indonesia ${ }^{12}$
}

\begin{abstract}
This study aims to test, analyze and explain the effect of motivation, work discipline and compensation on employee performance at PT XYZ partially and simultaneously that has a significant positive impact on PT XYZ's company. The study uses primary data obtained from the distribution of questionnaires containing respondents' opinions about motivation, work discipline and compensation for employee performance. The sampling method used is convenience sampling. of population 120 using slovin formula with an error rate of 0.05 can be 70 respondents who meet the criteria to be sampled. The analytical method used is multiple linear analysis using SPSS Version 20.0. these results indicate that there is a positive and partially significant effect on the motivation variable.
\end{abstract}

Keywords: Motivation, Work Discipline and Compensation for Employee, Performance

\section{Introduction}

\subsection{Preliminary}

Human resources are one of the most important factors in a company, both companies are seen from the human resources in the company, the importance of human resources is inseparable from the organization and all levels of management in the company, advancing current technological developments but the factor of human resources in the company is very important that can drive the success or running of a company [1]. The level of clean water services experienced by PT XYZ has a tendency to decrease from the target set. In a situation like this, company management cannot be predicted well, due to the lack of planning design in achieving goals. Furthermore, the development that occurs not only from the service, production and marketing factors. This development triggers changes in organizations that are driven by available human resources.

Meeting the needs of employees based on the quality and strength of the background of the slow performance of regional water companies. With so many similar companies serving clean water, companies are demanded to have competitiveness in order to maximize the performance of their employees so that clean water needs can be channeled well to consumers. In this case, the company analyzes the factors that can affect employee performance, to overcome this, human resources are the main factor in the company, because human resources are the driving wheel of the company and are very helpful to maximize company performance. 
Employee performance is a very important factor in a company to see the ability, quality of work, skills and time discipline that employees use in work. XYZ Company has a core business which is the fulfillment of clean water for the community members. thus, it requires a special relationship in processing water into raw water ready for consumption. Demands for the implementation of the company's core business are also carried out by each of the leadership and employees. Employees become the organizational driving force of the organization that needs support and encouragement from various regulatory instruments within the company.

The leadership of the board of directors has a strong influence on the success of achieving company goals and the magnitude of the motivation of its employees. According to Kasmir [2] factors that influence employee performance include the following: (1) Ability and Expertise, (2) Knowledge, (3) Work Design, (4) Personality, (5) Work Motivation, (6)) Leadership, (7) Leadership Style, (8) Organizational Culture, (9) Job Satisfaction, (10) Work Environment, (11) Loyalty, (12) Commitment, (13) Work Discipline.

From the various absences above, it can be explained that each factor influences one another. In this case the authors limit their analysis to improving employee performance seen from the management of human resources that are limited 3 Variables: 1) Motivation, 2) Discipline work and 3) Compensation. Motivation factor has an important role in improving employee performance in a company to achieve the planned company goals. Motivation has the meaning of a conscious effort to influence one's behavior so as to lead to the achievement of organizational goals, According to Berelson and Stainer [3].

To be able to continuously improve performance and achieve company goals by providing motivation for employees. Employee motivation by superiors plays an important role in fostering motivation for subordinates or employees because given the moral and material encouragement in the form of benefits is expected to be able to trigger him to further improve work results [4].

Motivation is an encouragement both from within and from outside the company to employees so that employees can provide the best in working for the company, the encouragement arises if the employee has met his needs by the company [5]. In this case Motivation affects employees at PT XYZ who do not meet the standards desired by the company, because there are undisciplined employees who come and take breaks on time, and to correct this or employee indiscipline the lack of strict sanctions applied by the company. Based on the facts that exist in the company following the attendance data recap which the author recap in the data one year past, namely January 2017 to January 2018 the details are as follows:

Table 1. Employee Attendance 2017-2018

\begin{tabular}{l|c|c|c|c|c}
\hline Discipline Indicator & $\mathbf{2 0 1 7}$ & $\mathbf{\%}$ & $\mathbf{2 0 1 8}$ & $\mathbf{\%}$ & Unit \\
\hline Alfa (Absent) & 29 & $20.3 \%$ & 37 & $24.5 \%$ & Time \\
Go home early & 39 & $27.3 \%$ & 45 & $31.5 \%$ & Time \\
Come not on time & 20 & $14 \%$ & 39 & $27.3 \%$ & Time \\
Sick & 40 & $28 \%$ & 49 & $34.3 \%$ & Time \\
\hline
\end{tabular}

From the results of the above data by the author the total number of employees used as a sample of 70 people consisting of 15 parts, in table 1.1 shows that for the last 3 (three) years there was no attendance indicating $100 \%$ attendance of employees except for corporate holidays such as company anniversary that requires all employees to attend, however attendance or absence includes various reasons for illness, permission, leave, and without reason. In addition to motivational factors, other factors that affect performance are work 
discipline, such as not working in accordance with company working hours, the daily attendance of employees, etc. Other than motivation and work discipline compensation based on employee workload is another factor also related to the performance. Compensation is an award or income in the form of money, direct goods and indirect goods received by employees.

According to Kasmir [6] compensation is the remuneration provided by the company to its employees, both financial and non-financial, which means that the company will provide compensation to all employees seen in it. Reward of services provided is the company's obligation for the efforts made to the company while working one of the factors in the effect of compensation in this study is that the salary received is not sufficient for daily needs, bonuses that are not appropriate, benefits and so forth. in the three factors Motivation, Work Discipline and Compensation that affect performance, performance also has the opposite effect [7], [8]. According to Dr. Kasmir [2]. Performance in English is performance, which means a person's achievement in carrying out the results of a task well and quickly, performance can be interpreted as the achievement of the goals set in the organization. One of the performance factors is that employees work ineffectively and efficiently, work procedures and tools that are used are not in accordance with SOP and others

Based on the description in the background of the problem above, the problem identification as follows: Lack of employee motivation at PT XYZ. Lack of company provides opportunities for employees to develop their potential. Lack of appreciation given from PT XYZ. Lack of strict sanctions given by the company to undisciplined employees. A decrease in the level of employee discipline at PT XYZ as seen from the number of attendances consisting of permits, alpha and going home not according to the hours set by the company There is no regulation on compensation for PT XYZ for employees who are deemed to have more workloads or jobs outside their part in this research in order to be carried out effectively and efficiently, it is necessary to limit the problems to be investigated. Given the wide range of issues that affect employee performance, the research is limited to employees at PT XYZ.

From the background description of the problem as mentioned above, the problem can be formulated as follows: What is the effect of work motivation on employee performance at PT XYZ? What is the effect of work discipline on employee performance at PT XYZ? What is the effect of compensation on employee performance at PT XYZ? How does simultaneous influence of work motivation, work discipline, and compensation have a significant influence on employee performance at PT XYZ? The intent and purpose of this study is that researchers try to describe the state of the company and the answers to the problems that have been made by researchers today and provide research results as input to the company. This research was conducted with the aim to: To analyze the effect of work motivation on employee performance at PT XYZ. To analyze the effect of work discipline on employee performance at PT XYZ. To analyze the effect of compensation on PT XYZ. To analyze the effect of work motivation, work discipline, compensation on employee performance at PT $\mathrm{XYZ}$

Based on the benefits and usefulness of research is as an effort to describe and as material for solving problems and making decisions in providing follow-up direction in the development of science and truth. Knowing and understanding from this research is expected to be beneficial in terms of: To be able to present the results of empirical data from each influence of motivation, work discipline, and compensation for improving employee performance at PT XYZ. The company is expected to be a source of information to look 
back at company policies relating to human resource management related to motivation, work discipline, and compensation for improving employee performance at PT XYZ.

For researchers, it is hoped to be one of the empirical study materials, especially regarding organizational behavior especially related to Motivation, Work Discipline, and Compensation for improving employee performance at PT XYZ. For the authors themselves, it is expected to be a separate experience in providing solutions to problem solving supported by theories that have been tested so as to provide a structured mindset in solving a problem.

\subsubsection{Motivation}

Motivation is something that gives rise to enthusiasm or work motivation as the intensity, direction and perseverance of efforts to achieve a goal according to G Terry [9], is a desire that contained in an individual who encourages him to do actions (behavior) [5], [4], [10]. Motivation is an impulse that directs a person to take certain actions to take risks requiring responsible feedback to have opportunities to excel and be innovative. By reaching the highest level in themselves or coming from outside they according Hezberg [5], [11] Dimensions of Motivation as follows: Intrinsic Factor: Incentives, Rewards for achievement, Salary, Extrinsic Factors: Relationships with coworkers, Work environment, Fair treatment

\subsubsection{Work Discipline}

Disciplinary Variable is the awareness and loyalty of a person to obey all company rules and social norms that apply and are enforced in a company, a company without having employees who have good discipline, it is difficult for the company to realize its goals. Veithzal [12], [13] said that discipline is a tool used to communicate with employees so that they are willing to change a behavior and as an effort to increase one's awareness and willingness to obey all applicable social rules and norms. Factors that influence discipline include: Attendance, Compliance with work regulations, Level of alertness, Need for selfesteem, Provision of promotion to potentially superior employees

\subsubsection{Compensation}

Compensation is balsa services provided by the company to its employees, both services provided by the company to its employees, both financial and non-financial. Compensation indicators are divided into two types, namely; Direct Compensation: Salary, incentives, Bonuses and Benefits. And Indirect Compensation: Insurance, Benefits, Leave and Pension Benefits [14], [15], [16], [17].

\subsubsection{The performance}

Performance in English is performance, which means a person's achievement in carrying out the results of a task well and quickly, performance can be interpreted as the achievement of the goals set in the organization. According to Robins [18] Performance indicators are divided into 3 types, namely: (1) Quality of Work, i.e. the quality of the work of employees within a certain time in accordance with work standards set by the organization, the indicators are accuracy, accuracy, cleanliness and hygiene; (2) Job Quantity is the number of jobs produced by employees in a certain time, and according to the number of jobs that are targeted and exceeds the amount targeted; (3) Timeliness is the accuracy in completing certain jobs in accordance with the specified time standards, the indicator is on time, faster or late [3], [19]. 


\section{Research Method}

Descriptive Analysis This research was conducted and examined the causes of a particular symptom to find a picture of performance [20], Multiple Regression Analysis Done after the data were collected using regression analysis collected using multiple linear regression analysis, the analysis used to determine whether there is an influence between the independent variables on the dependent variable. (1) Partial Hypothesis (t test), used to determine the significance of the independent variable on the dependent variable; (2) Simultaneous Hypothesis (Test F). The F test is used to determine whether an independent variable together significantly affects the dependent variable. To test the significance of multiple correlations.

\section{Results and Discussion}

\subsection{Validity and reliability test}

Motivation (X1) Test the validity with the help of SPSS through the process of respondent input $=70$ people and the level of significance $=5 \%$, then $\mathrm{df}=\mathrm{n}-1=69, \alpha=0.05$ obtained $\mathrm{r}$ table $=0.244$. Reliability Test on Education variable statement items where all statement items are declared valid and have a ralpha of $0.856>0.600$. Work Discipline (X2) Test the validity with the help of SPSS through the process of respondent input $=70$ people and the level of significance $=5 \%$, then $\mathrm{df}=\mathrm{n}-1=69, \alpha=0.05$ obtained $\mathrm{r}$ table $=0.244$. Reliability Test on Education variable statement items where all statement items are declared valid and have a Ralpha of $0.750>0.600$.

Compensation (X3) Test the validity with the help of SPSS through the process of respondent input $=70$ people and the level of significance $=5 \%$, then $\mathrm{df}=\mathrm{n}-1=69, \alpha=0.05$ obtained $r$ table $=0.244$. valid and has a ralpha of $0.862>0.600$. Performance (Y) Test the validity with the help of SPSS through the process of respondent input $=70$ people and the level of significance $=5 \%$, then $\mathrm{df}=\mathrm{n}-1=69, \alpha=0.05$ obtained $\mathrm{r}$ table $=0.244$. Reliability Test on Education variable statement items where all statement items are declared valid and have a ralpha of $0.858>0.600$

Table 2. Multiple Regression Analysis

\begin{tabular}{ccccc}
\hline & $\begin{array}{c}\text { Motivation } \\
(\mathrm{X} 1)\end{array}$ & $\begin{array}{c}\text { Work discipline } \\
(\mathrm{X} 2)\end{array}$ & $\begin{array}{c}\text { Compensation } \\
(\mathrm{X} 3)\end{array}$ & $\begin{array}{c}\text { The performance } \\
(\mathrm{Y})\end{array}$ \\
\hline Valid $N$ & 70 & 70 & 70 & 70 \\
Missing & 0 & 0 & 0 & 0 \\
The mean & 50.73 & 42.44 & 62.91 & 53.06 \\
Median & 51 & 43 & 64 & 54 \\
Mode & 48 & 40 & 60 & 54 \\
Std. Dive & 3,439 & 2,548 & 3,739 & 3,856 \\
Range & 20 & 10 & 23 & 22 \\
Minimum & 36 & 38 & 46 & 36 \\
Maximum & 56 & 48 & 69 & 58 \\
Sum & 3,551 & 2,971 & 4,404 & 3,714 \\
\hline
\end{tabular}

Source: Data processing results 
Motivation Variable (X1) Educational variable data obtained based on the results of measurements using a questionnaire that has a minimum score $=36$ and a maximum $=56$. The mean score is 50.73 , the median is 51 and the mode is 48 . The range of scores is 20 and the standard deviation is 3,439. Work Discipline Variable (X2) Data Discipline is obtained based on the results of measurements using a questionnaire that has a minimum score $=38$ and a maximum $=56$. The mean score is 50.71 , the median is 43 , and the mode is 48 . The range of scores is 10 and the standard deviation is 2,548.

Compensation Variable (X3) Data Discipline is obtained based on the results of measurements using a questionnaire that has a minimum score $=46$ and a maximum $=69$. The mean score is 62.91, median 64, and mode 60. The range of scores is 23 and the standard deviation is 3,739. Performance Variable (Y)Performance data was obtained based on the results of measurements using a questionnaire that had a minimum score $=36$ and a maximum $=58$. The mean score was 53.06 median 54 and mode 54 . The range of scores was 22 and the standard deviation was 3,856 .

Table 3: Multicollinearity Test

\begin{tabular}{|c|c|c|c|c|c|c|c|c|}
\hline \multicolumn{9}{|c|}{ Coefficients } \\
\hline \multirow{2}{*}{\multicolumn{2}{|c|}{ Model }} & \multicolumn{2}{|c|}{$\begin{array}{c}\text { Unstandardized } \\
\text { Coefficients }\end{array}$} & \multirow{2}{*}{$\begin{array}{c}\text { Standardized } \\
\text { Coefficients } \\
\text { Beta }\end{array}$} & \multirow[b]{2}{*}{$t$} & \multirow[b]{2}{*}{ Sig. } & \multicolumn{2}{|c|}{$\begin{array}{c}\text { Collinearity } \\
\text { Statistics }\end{array}$} \\
\hline & & $B$ & $\begin{array}{l}\text { Std. } \\
\text { Error }\end{array}$ & & & & Tolerance & VIF \\
\hline \multirow[t]{4}{*}{1} & (Constant) & 10,410 & 5,077 & & 2,051 & .444 & & \\
\hline & Motivation & .932 & .143 & .827 & 6,511 & .000 & 363 & 2,758 \\
\hline & Discipline & .202 & .184 & .135 & 1,100 & .275 & .389 & 2,571 \\
\hline & Compensation & .063 & 109 & .070 & .581 & .563 & .402 & 2,490 \\
\hline
\end{tabular}

Meanwhile, the VIF values for the three independent variables are Motivation (X1) 2.758, Work Discipline (X2) of 2.571, and Compensation (X3) of 2,490. All three variables have a VIF value $<10$. Thus, the results of this test show that Education, Motivation and Discipline not mutually correlating or multicollinearity does not occur in the regression model.

\subsection{Test Results}

In this study the authors used the t test to test hypothesis $1(\mathrm{H} 1)$, hypothesis 2 (H2), hypothesis $3(\mathrm{H} 3)$ which had been explained in the previous chapter. In this t test if the calculated $t$ value is greater than $t$ table and the significance value of the calculation is smaller than 0.5 , it can be said that the hypothesis that there is a significant influence of independent variables on the dependent variable. T value was obtained from the results of questionnaire data processing using SPSS which can be seen in the following table:

Table 4. Tcount and Significance

Motivational Variables (X1) with Performance Variables (Y)

\section{Coefficients (a)}

\begin{tabular}{cccccc}
\hline & $\begin{array}{c}\text { Unstandardized } \\
\text { Coefficients }\end{array}$ & $\begin{array}{c}\text { Standardized } \\
\text { Coefficients }\end{array}$ & t & Sig. \\
Model & B & Std. Error & Beta & \\
\hline
\end{tabular}




\begin{tabular}{rrrrrr}
\hline (Constant) & 8,592 & 4,356 & & 1973 & .053 \\
Motivation & .877 & .86 & .779 & 1031 & .000 \\
\hline
\end{tabular}

Dependent Variable: Performance

Source: SPSS processing results.

Through the t-test to test the magnitude of the influence of variables namely Motivation variables to the dependent variable, namely Performance This test is done by comparing between $\alpha$ (alpha) at $\mathrm{Y}=8.592+0.877 \mathrm{X}, \mathrm{Y}=$ Performance, $\mathrm{X}=$ Motivation. a significant level for the two-sided test of 5\%. T test produces tcount $=10,231$ greater than table $=1,973$ which means that the Motivation variable has a significant effect on the Performance variable. Test Results $F$ To find out whether the relationship between the independent variables $\mathrm{XI}, \mathrm{X} 2$, and $\mathrm{X} 3$ on the dependent variable $\mathrm{Y}$ is simultaneously significant or not, an $\mathrm{F}$ test is performed. From the results of calculations using the SPSS program, the F-Test results obtained at the level of significant $(\alpha)=0,05$.

Table 5. Calculate and Significance of Educational Variables (X1), Simultaneous Motivation (X2) and Discipline (X3)

Against Performance (Y)

\begin{tabular}{rrrrrrr}
\multicolumn{7}{c}{ ANOVAb } \\
\hline \multirow{2}{*}{ Model } & & Sum of Squares & df & Square & \multicolumn{1}{c}{ F } & \multicolumn{1}{c}{ Sig. } \\
\hline 1 & Regression & 621,934 & 3 & 207,311 & 34,919 & $.000 \mathrm{a}$ \\
& Residual & 391,837 & 66 & 5937 & & \\
& Total & 1013,771 & 69 & & & \\
\hline
\end{tabular}

a. Predictors: (Constant), Education, Motivation, Discipline

b. Dependent Variable:

Performance

According to the table above it is known that Fcount $=34.919$ is greater than Ftable $=$ 2.334, because Fcount $>$ Ftable then Ho

probability value $=0,000<\alpha=0.05$ then $\mathrm{Ho}$ is rejected and Ha. accepted, which means the variables Motivation, Discipline and Compensation have a significant effect together on Performance rejected and Ha accepted. While the F test is done by looking at the probability of the significance of the yield

\section{Conclusions}

Based on the results of data analysis, the research conclusions can be drawn and submitted as follows: Motivation variable partially has a positive and significant effect on the performance variables of employees who work at PT XYZ., Disciplinary variables partially have a positive and significant influence on the performance variables of employees who work at PT XYZ. The compensation variable partially has a positive and significant effect on 
the performance variables of employees who work at PT XYZ. Motivation, Discipline and Compensation variables partially have a positive and significant effect on the performance variables of employees who work at PT XYZ

\section{References}

[1] W. H. Reid, "Human resources," Handbook of Mental Health Administration and Management. 2013, doi: 10.4324/9781315777221-3.

[2] M. . Dr. Kasmir M.M., "Manajemen Sumber Daya Manusia (Teori dan Praktik)," in Manajemen Sumber Daya Manusia (Teori dan Praktik), 2016.

[3] L. Stainer, "Performance management and corporate social responsibility: the strategic connection," Strateg. Chang., 2006, doi: 10.1002/jsc.761.

[4] K. A. Roni, A. Moein, and N. I. Effendi, "Determination of Work Motivation and its Implication on Employee Performance Secretariat of Kpu Se-Province Jambi," Int. Rev. Manag. Mark., 2018.

[5] C.-R. Giroux, "The Motivation to work, by F. Herzberg, B. Mausner and B.-C. Snyderman, John Wiley \& Sons, New York, John Wiley \& Sons, 1959.," Relations Ind., 2017, doi: 10.7202/1022040ar.

[6] M. Javed, R. Balouch, and F. Hassan, "Determinants of Job Satisfaction and its impact on Employee performance and turnover intentions," Int. J. Learn. Dev., 2014, doi: 10.5296/ijld.v4i2.6094.

[7] S. Dobrow Riza, Y. Ganzach, and Y. Liu, "Time and Job Satisfaction: A Longitudinal Study of the Differential Roles of Age and Tenure," J. Manage., 2018, doi: 10.1177/0149206315624962.

[8] K. Breevaart, A. Bakker, J. Hetland, E. Demerouti, O. K. Olsen, and R. Espevik, "Daily transactional and transformational leadership and daily employee engagement," J. Occup. Organ. Psychol., 2014, doi: 10.1111/joop.12041.

[9] T. A. Monoarfa and O. Usman, "How does service quality impact the behavioral intentions of full-service airline passengers through a hierarchical model?," Manag. Sci. Lett., 2020, doi: 10.5267/j.msl.2020.7.008.

[10] F. N. Al-Madi, H. Assal, F. Shrafat, and D. Zeglat, "The Impact of Employee Motivation on Organizational Commitment," Eur. J. Bus. Manag., 2017.

[11] D.-B. Kwasi and A. George, "Application of Frederick Herzberg's Two-Factor theory in assessing and understanding employee motivation at work: a Ghanaian Perspective Kwasi," Phys. Chem. Chem. Phys., 2000.

[12] V. R. Zainal, "Manajemen Sumber Daya Manusia," Manaj. sumber daya Mns. untuk Perusah. dari Teor. ke Prakt., 2015.

[13] V. Rivai, Bachtiar, and R. B. Amar, "Pemimpin dan Kepemimpinan dalam Organisasi," Frum Ilm., 2014, doi: 10.1016/j.eururo.2010.11.021.

[14] E. R. and E. Development, "Handbook for a measuring employee performance," Work. Compens. Perform. Serv., 2011.

[15] B. Gerhart, "Compensation," in The Routledge Companion to Strategic Human Resource Management, 2008.

[16] P. C. Bryant and D. G. Allen, "Compensation, Benefits and Employee Turnover," Compens. Benefits Rev., 2013, doi: 10.1177/0886368713494342.

[17] K. Khalid and S. Nawab, "Employee Participation and Employee Retention in View of Compensation," SAGE Open, 2018, doi: 10.1177/2158244018810067.

[18] S. P. Robbins and T. A. Judge, Organizational Behavior 15th Edition. 2013.

[19] H. J. Whiting, T. J. B. Kline, and L. M. Sulsky, "The performance appraisal congruency scale: An assessment of person-environment fit," Int. J. Product. Perform. Manag., 2008, doi: 10.1108/17410400810857239. 
[20] Sugiyono, "Metode Penelitian Kuantitatif, Kualitatif dan R \& D.Bandung:Alfabeta.," Metod. Penelit. Kuantitatif, Kualitatif dan R D.BandungAlfabeta., 2012, doi: 10.1017/CBO9781107415324.004. 